\title{
Quality Assessment of Groundwater in the Lower Litani Basin (LLRB), Lebanon
}

\author{
Nada Nehme ${ }^{1}$, Chaden Moussa Haydar ${ }^{1}$, Amani Dib ${ }^{1}$, Nawal Ajouz ${ }^{1}$, Khaled Tarawneh²* \\ ${ }^{1}$ Faculty of Agricultural Engineering and Veterinary Medicine, Lebanese University, Beirut, Lebanon \\ ${ }^{2}$ Amman Arab University, Faculty of Engineering, Civil Engineering Department, Amman, Jordan
}

Email: khtarawneh62@yahoo.com

\begin{abstract}
Lebanon is a small mountainous country with a typical Mediterranean climate with a large spatial variability of rainfall, a substantial amount of which is in the form of snow. In addition, the country is strongly urbanized with a great anthropic pressure on the water resources. the cost of waterresources degradation in the Upper Litani River Basin (ULRB) was estimated at $\$ 227$ million, which is equivalent, on average, to $2.2 \%$ of the GDP in the ULRB and $0.5 \%$ of the GDP at the current national GDP of Lebanon.

The contamination of groundwater in the lower Litani River Basin (LLRB) has in recent years become highly vulnerable. Thus, anthropogenic pressure, high infiltration of karistic aquifer features, and excessive usage of fertilizers resulted in extensive pollution stress.

This article aims to understand ground water quality of the LLRB by studying the physicochemical characteristics of ground water, the levels of bacteria and heavy metals in this river. In addition to evaluate the influence of human activities on groundwater quality at different sites. Microbiological pollution was dominant in all sites unlike the heavy metals pollution, which was detected through the presence of lead and copper parameters solely. Elevated levels of sulfate and calcium were perceived in all sites with the total absence of phosphate. High levels of nitrate was found in all localities, except in Chhour (1, 2, 3), Arzoun (1 and 2) and Kaakeih el Jese. As for lead, high levels were predominant everywhere except in Tar Felsai, Chhour (3), Arzoun (1 and 2) and Kaakeih el Jeser sites. Ammonium levels were low in Borj Rahal, and Ain Abou Abdallah (2). The principal component analysis (PCA) indicated that the Zahrani site is the most polluted. Most sources of pollution are related to wastewater discharges, agricultural activities and industrial activities. In addition to monitoring groundwater quality, it is of prime importance to consider it as an integral component for the management of water resources of the lower Litani basin.
\end{abstract}

Keywords: Lebanon, contamination, LLRB, groundwater, PCA

\section{Introduction}

The Litani River Basin (LRB) having an area of $2110 \mathrm{~km}^{2}$ is the largest watershed in Lebanon and is equivalent to about $20 \%$ of total Lebanese territory. The Litani River flows in Lebanon over $174 \mathrm{~km}$, and it has $60 \mathrm{~km}$ of tributaries. The basin enjoys a variety of climates ranging from coastal subtropical to dry continental. It comprises 263 villages in twelve districts of four governments. The water flowing into the Litani River accounts for about 30\% of the water flowing in all Lebanese rivers [1] [2] [3] [14]. Litani River is also a major source of hydropower generation, providing about $20 \%$ of national energy production in the form of non-polluting hydropower. The LRB lies between the following geographic coordinates $33^{\circ} 06^{\prime} 25^{\prime \prime} \mathrm{N}$ and $34^{\circ} 04^{\prime} 05^{\prime \prime} \mathrm{N}$ and $35^{\circ} 14^{\prime} 40^{\prime \prime} \mathrm{E}$ and $36^{\circ} 22^{\prime} 44^{\prime \prime} \mathrm{E}$.

This river is divided into two hydrologic units (i.e. Sub-Basins): The Upper Sub-basin (USB) that extends from northern springs feeding the river to Qaraaoun Lake, and a Lower Sub-basin (LSB) between the lake to the Mediterranean Sea. Several sources of pollution are spread along this river. Groundwater quality data was collected from a few perforated wells in the three main aquifer layers, Quaternary, Cenomanian and Cambanian.

The uncontrolled proliferation of illicit private drilling for irrigation purposes in addition to excessive use of fertilizers in intensive agriculture resulted in deterioration of the water quality [7] [8] [14]. Both the water quality of most aquifers on the coastal plains and the infiltration of nitrates in high concentrations 
were direct causative agents of the pollution in the water table. The pollution in the Litani basin as well as the Qaraoun dam has reached an alarming level resulting in mobilization of the responsible parties both at the level of the Litani Office and the Ministry of the Environment. This is attributed to the fact that in the Bekaa district pesticides, industrial and sanitary residues are directly discharged at the river level or through infiltration at the groundwater level without a filtering station and without precautions, polluting both the basin and Qaraoun Lake [4] [5] [3].

In response to several studies conducted on pollution of water resources, the National office of Litani (NOOL), highlighted the different sources of pollution such as: bacteriological residues, fecal contamination, the concentration of iron, zinc and mercury following the spill by the companies deprived of their residues. This had led to disturbance and imbalance of the ecosystem resulting in anaerobic fermentation at the water level and bad odors in the ambient air. This pollution had adverse effects on the health of the population

The strategic importance of good groundwater quality to protect the ground water is very important in LLRB.

\section{$2 \quad$ Study Area}

The study area represents the ground water in lower litany basin characterized by an average altitude of about $600 \mathrm{~m}$ with a total area of $616 \mathrm{~km}^{2}$ [1] [6]. The lower Litani basin was selected due to its hydrological importance as it joins three provinces: South, Bekaa and Nabatiyeh. The studied region encompassed diverse socio-economic and agricultural activities. The tourism is considered as a prime sector, that while several touristic sites were identified.

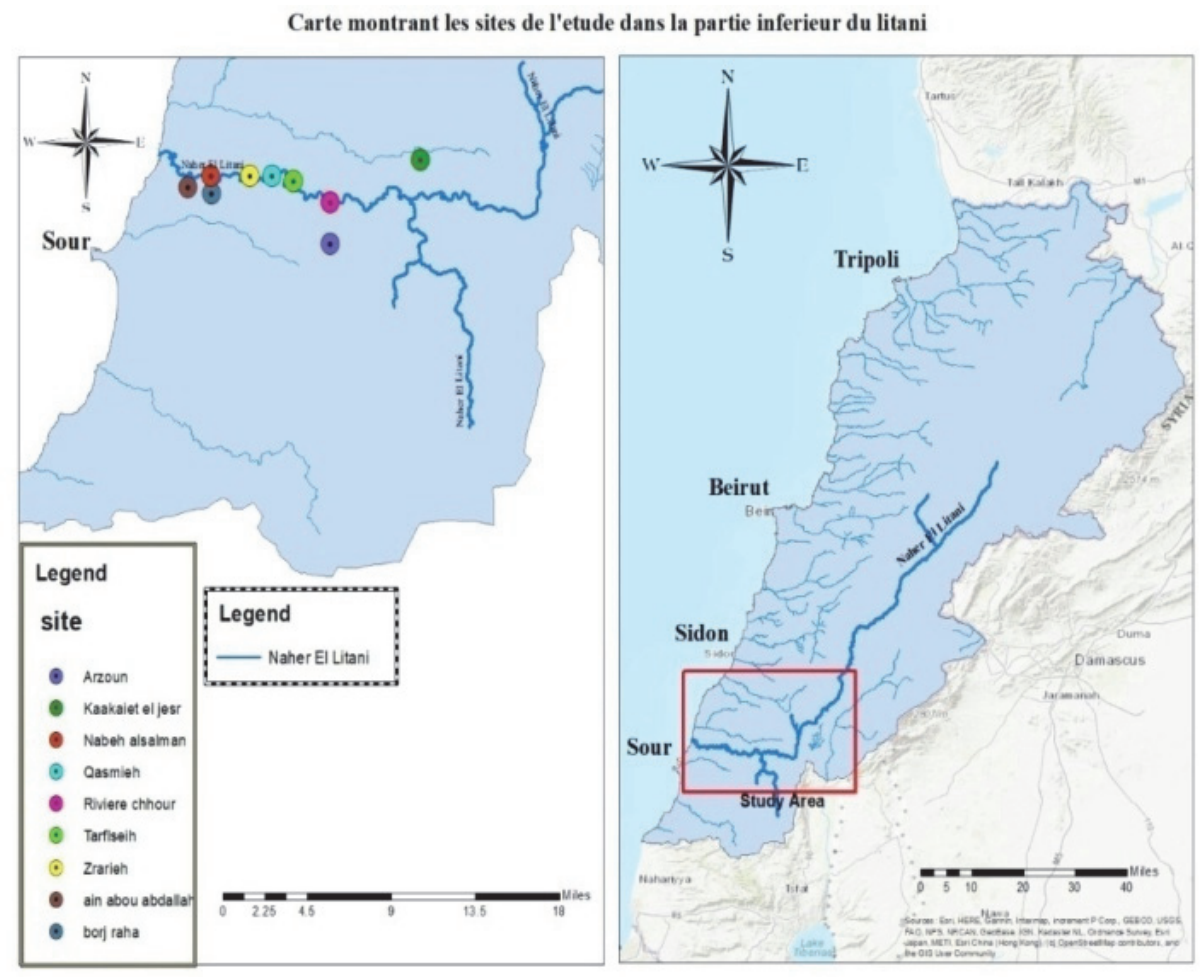

Figure 1. Map showing the study sites. 


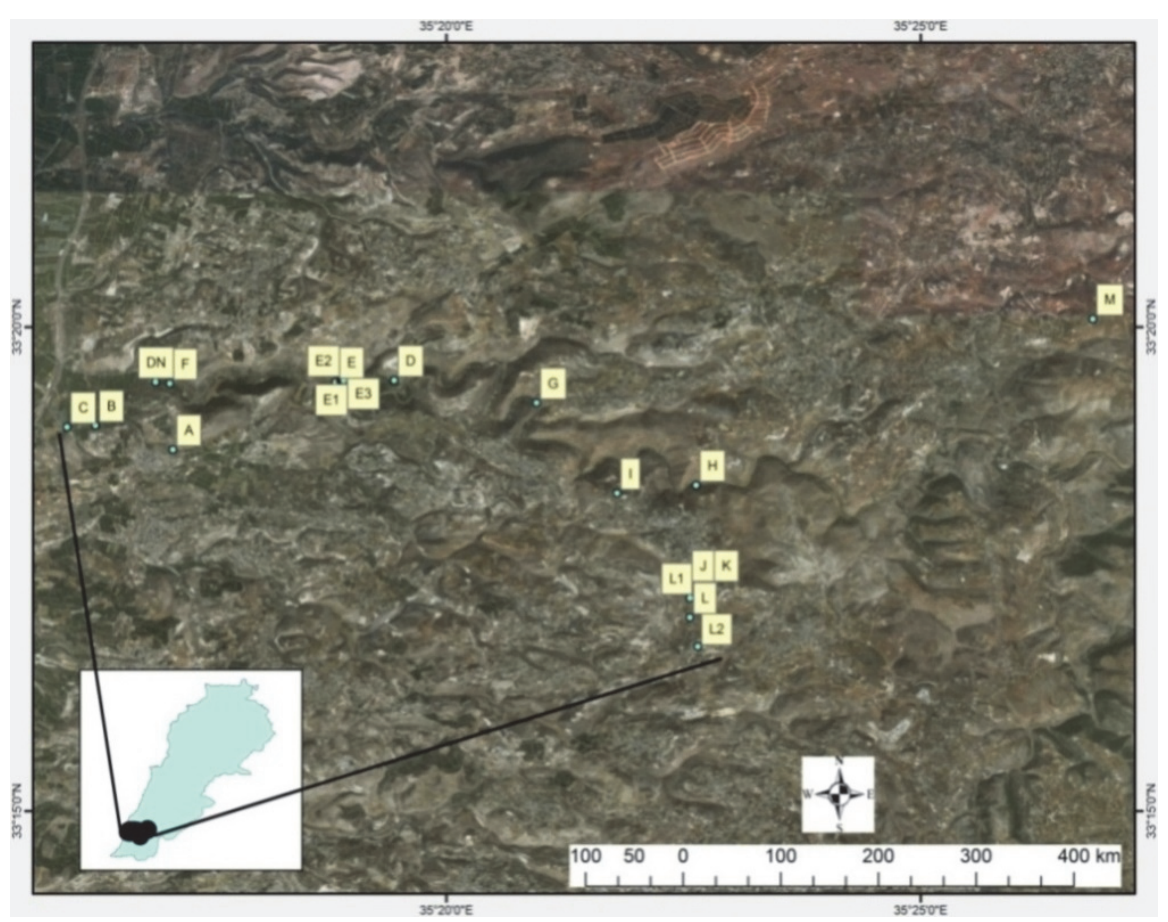

Figure 2. GIS map of the study sites.

Table 1. Coordinates of the sites of our study and the types of activities.

\begin{tabular}{|c|c|c|c|c|}
\hline Location & Latitude & Longitude & Altitude & Types of economic activities \\
\hline BorjRahal & $33^{\circ} 18^{\prime} 44^{\prime \prime} \mathrm{N}$ & $35^{\circ} 17^{\prime} 07^{\prime \prime} \mathrm{E}$ & $175 \mathrm{~m}$ & Agricultural zone, and irrigation \\
\hline Ain Abou Abdallah 1 & $33^{\circ} 18^{\prime} 59^{\prime \prime} \mathrm{N}$ & $35^{\circ} 16^{\prime} 18^{\prime \prime} \mathrm{E}$ & $15 \mathrm{~m}$ & Agricultural zone and irrigation \\
\hline Ain Abou Abdallah 2 & $33^{\circ} 18^{\prime} 58^{\prime \prime} \mathrm{N}$ & $35^{\circ} 16^{\prime} 00^{\prime \prime} \mathrm{E}$ & $10 \mathrm{~m}$ & Agricultural zone and tourist zone \\
\hline Qasmieh & $33^{\circ} 19^{\prime} 27^{\prime \prime} \mathrm{N}$ & $35^{\circ} 19^{\prime} 27^{\prime \prime} \mathrm{E}$ & $30 \mathrm{~m}$ & Urban area, irrigation canal - tourist area \\
\hline Rivière Qasmieh & $33^{\circ} 19^{\prime} 26^{\prime \prime} \mathrm{N}$ & $35^{\circ} 16^{\prime} 56^{\prime \prime} \mathrm{E}$ & $13 \mathrm{~m}$ & $\begin{array}{l}\text { Urban area, irrigation canal, tourist area, } \\
\text { agricultural }\end{array}$ \\
\hline Zrarieh & $33^{\circ} 19^{\prime} 26^{\prime \prime} \mathrm{N}$ & $35^{\circ} 18^{\prime} 50 " \mathrm{E}$ & $27 \mathrm{~m}$ & $\begin{array}{l}\text { Urban area, irrigation canal agricultural areas } \\
\text { tourist area agricultural cover }\end{array}$ \\
\hline Zrarieh 1 & $33^{\circ} 19^{\prime} 27^{\prime \prime} \mathrm{N}$ & $35^{\circ} 18^{\prime} 53^{\prime \prime} \mathrm{E}$ & $24 \mathrm{~m}$ & $\begin{array}{l}\text { Urban area, irrigation canal agricultural areas } \\
\text { tourist area agricultural cover }\end{array}$ \\
\hline Zrarieh 2 & $33^{\circ} 19^{\prime} 27^{\prime \prime} \mathrm{N}$ & $35^{\circ} 18^{\prime} 54^{\prime \prime} \mathrm{E}$ & $21 \mathrm{~m}$ & $\begin{array}{l}\text { Urban area, irrigation canal agricultural areas } \\
\text { tourist area agricultural cover }\end{array}$ \\
\hline Zrarieh 3 & $33^{\circ} 19^{\prime} 27^{\prime \prime} \mathrm{N}$ & $35^{\circ} 18^{\prime} 55^{\prime \prime} \mathrm{E}$ & $19 \mathrm{~m}$ & $\begin{array}{l}\text { Urban area, irrigation canal agricultural areas } \\
\text { tourist area agricultural cover }\end{array}$ \\
\hline Nabeh El Salman & $33^{\circ} 19^{\prime} 25^{\prime \prime} \mathrm{N}$ & $35^{\circ} 17^{\prime} 05^{\prime \prime} \mathrm{E}$ & $9 \mathrm{~m}$ & Potable water \\
\hline Tar Felsai & $33^{\circ} 19^{\prime} 13^{\prime \prime} \mathrm{N}$ & $35^{\circ} 20^{\prime} 57^{\prime \prime} \mathrm{E}$ & $37 \mathrm{~m}$ & Agricultural Zone-Irrigation-Tourist Zone \\
\hline Rivière Chhour & $33^{\circ} 18^{\prime} 22^{\prime \prime} \mathrm{N}$ & $35^{\circ} 22^{\prime} 38^{\prime \prime} \mathrm{E}$ & $57 \mathrm{~m}$ & Touristic zone \\
\hline Chhour 1 & $33^{\circ} 18^{\prime} 17^{\prime \prime} \mathrm{N}$ & $35^{\circ} 21^{\prime} 48^{\prime \prime} \mathrm{E}$ & $376 \mathrm{~m}$ & Touristic zone \\
\hline Chhour 2 & $33^{\circ} 17^{\prime} 20^{\prime \prime} \mathrm{N}$ & $35^{\circ} 22^{\prime} 48^{\prime \prime} \mathrm{E}$ & $580 \mathrm{~m}$ & Potable water-urban area \\
\hline Chhour 3 & $33^{\circ} 17^{\prime} 20^{\prime \prime} \mathrm{N}$ & $35^{\circ} 22^{\prime} 47^{\prime \prime} \mathrm{E}$ & $398 \mathrm{~m}$ & Potable water - urban area \\
\hline Arzoun & $33^{\circ} 17^{\prime} 00^{\prime \prime} \mathrm{N}$ & $35^{\circ} 22^{\prime} 34^{\prime \prime} \mathrm{E}$ & $332 \mathrm{~m}$ & Potable water \\
\hline Arzoun 1 & $33^{\circ} 17^{\prime} 12^{\prime \prime} \mathrm{N}$ & $35^{\circ} 22^{\prime} 34^{\prime \prime} \mathrm{E}$ & $366 \mathrm{~m}$ & Urban zone - agriculture zone \\
\hline Arzoun 2 & $33^{\circ} 16^{\prime} 42^{\prime \prime} \mathrm{N}$ & $35^{\circ} 22^{\prime} 39^{\prime \prime} \mathrm{E}$ & $560 \mathrm{~m}$ & Irrigation - agricultural zone \\
\hline Kaakeih El Jeser & $33^{\circ} 20^{\prime} 05^{\prime \prime} \mathrm{N}$ & $35^{\circ} 26^{\prime} 49^{\prime \prime} \mathrm{E}$ & $492 \mathrm{~m}$ & Irrigation - agricultural zone \\
\hline
\end{tabular}




\section{$3 \quad$ Water Sampling and Treatment Methods}

Representative water samples were collected from various locations of the study area. In order to characterize and quantify the pollution factor adequately, cations and anions as well as bacterial parameters were assessed. Water samples were stored in cool boxes and transported to the laboratory for undergoing subsequent analysis. At each sampling site, approximately $2000 \mathrm{ml}$ of raw water was withdrawn.

Five types of bacteria were investigated: total Coliforms, Escherichia coli, Salmonella, Clostridium Perfringens and Staphylococcus Aureus. For each bacteria type, a specific culture medium was prepared. After coagulation of the culture media, a small plastic rod was placed in each sample and one box of each culture medium was inoculated. Whenever the sample was changed, the stem would be sterilized with the Bunsen burner and alcohol. In the case of Clostridium Perfringens, the inoculation loop was tilted at 60 $\mathrm{C}^{\mathrm{O}}$ and the filament was heated to red through its entire length to avoid any contamination before cooling it and incorporating it into the sample for final tube inoculation. After the end of seeding, each type of culture medium was put at a suitable temperature and for a determined time.

\section{$4 \quad$ Results and Discussion}

\subsection{Microbiological Analysis}

Total Coliform is a group of bacteria that are frequently found in the environment, for example in soil or vegetation, as well as in the intestines of mammals, including humans. Their presence in water indicate recent fecal contamination and/or the possible presence of disease-causing pathogens. It was found that all sites are contaminated with total Coliform except Ain Abou Abdallah (1). Some of sites have extremely high contamination level that exceeding the acceptable limit set by WHO $(0 \mathrm{mg} / \mathrm{l})$

Table 2. The microbiological analysis results of the sites.

\begin{tabular}{lccccc}
\hline \multicolumn{1}{c}{ Location } & $\begin{array}{c}\text { Total } \\
\text { Coliforms }\end{array}$ & $\begin{array}{c}\text { Eishersha } \\
\text { coli }- \text { EC }\end{array}$ & Salmonela & $\begin{array}{c}\text { Staphylococcus } \\
\text { Aureus }\end{array}$ & $\begin{array}{c}\text { Clostridim } \\
\text { perfringens }\end{array}$ \\
\hline Borj Rahal & 113 & $>1000$ & 1 & $>1000$ & 0 \\
Ain Abou Abdallah 1 & 0 & 0 & 108 & $>1000$ & 0 \\
Ain Abou Abdallah 2 & 6 & 0 & 1 & 60 & 0 \\
Qasmieh & $>1000$ & $>1000$ & 0 & 10 & 0 \\
River Qamieh & 1000 & 34 & $>1000$ & $>1000$ & 0 \\
Zrarieh & 50 & 4 & 0 & $>1000$ & 0 \\
Zrarieh 1 & 119 & 34 & 1 & $>1000$ & 0 \\
Zrarieh 2 & 15 & 276 & 0 & $>1000$ & 0 \\
Zrarieh 3 & 222 & 68 & 15 & $>1000$ & 0 \\
Nabeh al salman & 65 & 2 & 3 & $>1000$ & 0 \\
Tar Felsai & 9 & 45 & 2 & $>1000$ & 0 \\
River Chhour & 102 & 75 & $>1000$ & 152 & 0 \\
Chhour 1 & 25 & 200 & $>1000$ & $>1000$ & 0 \\
Chhour 2 & 1000 & $>1000$ & 180 & 195 & 0 \\
Chhour 3 & 120 & $>1000$ & 8 & $>1000$ & 0 \\
Arzoun & 10 & $>1000$ & 18 & $>1000$ & 0 \\
Arzoun 1 & 50 & 50 & $>1000$ & $>1000$ & 0 \\
Arzoun 2 & 25 & 40 & 0 & $>1000$ & 0 \\
Kaakaeih el Jeser & $>1000$ & 180 & 0 & $>1000$ & \\
\hline
\end{tabular}

Escherichia coli is the only member of the total Coliform group found exclusively in the intestines of mammals including humans. It is also found in the intestines of some animals. Most types of E. coli are harmless and even help to keep your digestive tract healthy. However, some strains can cause diarrhea in the case of eating contaminated food or drinking dirty water. After enumeration of these bacteria it was 
found that all sites were contaminated with Escherichia coli except Ain Abou Abdallah (1, 2), and there are sites which have a very high contamination rate as shown in Table 2 and which exceed the acceptable limit set by WHO (0 mg/L).

Salmonella are mesophilic bacteria with an optimum growth temperature of $35 / 37 \mathrm{C}^{\circ}$. Furthermore, Salmonella can grow from $5^{\circ} \mathrm{C}$ to $45 / 47^{\circ} \mathrm{C}$ with growth significantly delayed by temperatures below $10 \mathrm{C}^{\circ}$ [3]. After enumeration of this bacterium, all sites were found to be contaminated with Salmonella except sites of Qasmieh, Zrarieh, Zrarieh (2), Arzoun (2) and Kaakeih El Jeser sites.

Staphylococcus Aureus, otherwise known as coagulase-positive Staphylococcus is a gram-positive bacterium. It is a Coccus with various forms such as: rounded form, diplococcic (coccis associated with two), or in the form of clusters having bunches of grapes. After counting these bacteria, it was found that all sites are contaminated with this bacterium. Some sites demonstrated very high levels of contamination exceeding the standard limit.

Clostridium Perfringens is a gram-positive, non-motile, anaerobic and sporulated bacillus bacterium. It is found in the intestines of animals and humans, as well as in the environment in soil, sewage or dust. It produces and secretes many toxins and hydrolytic enzymes. After enumeration of this bacterium, it was found that no site was contaminated by this type of bacteria.

\subsection{Physicochemical Parameters}

Table 3. The T, PH and EC values of the different sites.

\begin{tabular}{lcccc}
\hline Names capitalization & Temperature $(\mathbf{T})$ & EC $\boldsymbol{\mu s} / \mathbf{c m}$ & PH & TDS ppm \\
\hline Borj Rahal & 32 & 460 & 7.17 & 230 \\
Ain Abou Abdallah 1 & 33 & 530 & 7.25 & 270 \\
Ain Abou Abdallah 2 & 34 & 520 & 7.15 & 260 \\
Qasmieh & 33 & 550 & 7.12 & 270 \\
Rivier Qamieh & 32 & 380 & 7.55 & 180 \\
Zrarieh & 35 & 500 & 7.39 & 250 \\
Zrarieh 1 & 35 & 450 & 7.16 & 230 \\
Zrarieh 2 & 34 & 430 & 7.33 & 220 \\
Zrareih 3 & 33 & 450 & 7.32 & 220 \\
Nabeh al salman & 30 & 500 & 6.86 & 250 \\
Tar Felsai & 31 & 530 & 7.01 & 260 \\
Rivier Chhour & 33 & 320 & 7.23 & 160 \\
Chhour 1 & 32 & 440 & 6.81 & 220 \\
Chhour 2 & 30 & 410 & 6.90 & 200 \\
Chhour 3 & 32 & 220 & 6.96 & 110 \\
Arzoun & 33 & 240 & 7.35 & 120 \\
Aroun 1 & 35 & 510 & 7.24 & 250 \\
Arzoun 2 & 31 & 410 & 6.79 & 200 \\
Kaakeih el Jeser & 35 & 410 & 6.95 & 200 \\
\hline
\end{tabular}

\subsubsection{Temperature}

The temperature of the water is an ecological factor which causes important ecological repercussions. It is one of the basic descriptors of the environmental knowledge. The temperature influences both the biological activity on which the total production depends and the distribution of the species (thermal referendums). Our measurements demonstrated the fact that the temperature of the samples taken were between $30 \mathrm{C}^{\circ}$ and $35 \mathrm{C}^{\circ}$. These temperatures are within the adequate limits for this time of the year (May).

\subsection{2. $\mathrm{PH}$}

The hydrogen potential, denoted $\mathrm{pH}$ is a measure of the chemical activity of hydrons (also commonly called protons or hydrogen ions) in solution. The $\mathrm{pH}$ scale extends in practice from 0 (very acidic) to 14 (very alkaline). The median value 7 corresponds to a neutral solution at $25^{\circ} \mathrm{C}$. The $\mathrm{pH}$ of natural water can vary from 4 to 10 depending on the acidic or basic nature of the lands crossed. Low pH (acidic waters) 
increases the risk of metals in a more toxic ionic form. High $\mathrm{pH}$ increases ammonia concentrations, toxic to fish. $\mathrm{pH}$ values for various sites ranged from 6.80 to 7.55. Those values are more or less neutral to slightly basic. As a matter of fact, $\mathrm{pH}$ of all sites falls within the acceptable ranges set by the WHO organization ( $\mathrm{pH}$ between 6.5 and 8.5).

\subsubsection{Electrical Conductivity (EC)}

Electrical conductivity characterizes the ability of a material or solution to let the electric charges move freely allowing the passage of an electric current. The higher the concentration of ions, the easier the liquid will conduct the electric current causing an elevation in EC values. Perfectly pure water does not contain ions and cannot carry an electric current. Theoretically, the electrical conductivity will be zero. The EC values of selected sites are between $320-550 \mu \mathrm{s} / \mathrm{cm}$, except for $\mathrm{K}$ and L. There is a very strong relationship between conductivity and mineralization according to the French regulations. All the values of the electrical conductivities are between (380-666 $\mu \mathrm{s} / \mathrm{cm})$, therefore all sites have an accentuated mineralization.

\subsubsection{TDS (Total Dissolved Solids)}

The TDS also gives an estimate of the salt content present in the nutrient solution. It means all the dissolved solids and represents the total concentration of the substances dissolved in the water. The measure includes the measurement of organic and mineral salts. TDS values of various sites vary between 110 and $280 \mathrm{ppm}$. TDS and EC values of these sites confirm the proportional relationship between these two parameters.

\subsubsection{Concentrations of anions in water}

Measurement of the anions Nitrate $\left(\mathrm{NO}_{3}{ }^{-}\right)$, Sulfate $\left(\mathrm{SO}_{4}{ }^{2-}\right)$, Phosphate $\left(\mathrm{PO}_{4}{ }^{3-}\right)$ and Chloride $\left(\mathrm{CL}^{-}\right)$was carried out by using the spectrometer apparatus. The samples were prepared at the beginning, after which the absorbance was read by a photometer flame. Finally, the concentration of each element was calculated using a calibration curve.

Nitrates are the final stage of nitrogen oxidation, and represent the highest nitrogen form of oxidation present in water. They provide nitrogen to the plant and are known to be the most problematic. In fact, brought in excess, they can cause several negative impacts on the crops amongst which we mention delays of maturation and an alteration of the quality. The concentrations in the various sites range between 135$800 \mathrm{~m} / \mathrm{L}$, except in the sites of Chhour (1, 2, 3), Arzoun, Arzoun (1,2) and kaakeih el Jeser which demonstrated 0 figures. Those values fall within the acceptable WHO limits (which is equal to $50 \mathrm{mg} / \mathrm{L}$ ) and indicate absence of contamination due to this element.

Sulfates can be found in all natural waters. The origin of most sulfate compounds is the oxidation of sulfite ores, the presence of shale, or industrial waste. Other origins are erosion of rocks and seawater. A high sulfate content (copper sulfate) can cause digestive disorders (gastrointestinal irritation, diarrhea), liver and renal toxicity. The sulfate concentrations measured are between $400-4470 \mathrm{mg} / \mathrm{L}$. where the highest concentration is at Arzoun (1) $(4461.5384 \mathrm{mg} / \mathrm{L})$. However, the Chhour (2, 3) and Arzoun (2) sites have sulfate concentrations below the acceptable limit by WHO (250 mg /L) [9].

Phosphorus is an essential element in the development of all living organisms and it exists in nature. During the laboratory analysis process, no color change was observed in the beakers containing the samples except in Ain Abou Abdallah (1) which revealed a weak color. This indicates that the amount of phosphate is negligible in our samples.

Chloride is essential for the body's water balance and is naturally present at low levels in mineral waters. However, industrial pollution can accidentally increase it to concentrations that are unfit for consumption. Generally, chlorides are used for disinfection purposes. Investigated sites showed acceptable values that did not exceed the limit determined by the WHO (which is equal to $250 \mathrm{mg} / \mathrm{L}$ ). Thus, no contamination due to this element is the case.

\subsubsection{Concentrations of cations in water}

Measurement of the Calcium $\left(\mathrm{Ca}^{2+}\right)$, Magnesium $\left(\mathrm{Mg}^{2+}\right)$, Potassium $\left(\mathrm{K}^{+}\right)$, Sodium $\left(\mathrm{Na}^{+}\right)$, Ammonium $\left(\mathrm{NH}^{4+}\right)$ and heavy metals $(\mathrm{Pb}, \mathrm{Cu}, \mathrm{Zn}, \mathrm{Cd}, \mathrm{Cr}, \mathrm{Fe})$ was carried out by spectrometer and flame photometer. Before passing the samples, we realized the filtration syringe whereby the filter was fixed with a cellulose acetate membrane. The sterile membranes have a pore size of $0.45 \mu \mathrm{m}$ for the filtration of fine particles. 
The solutions were first diluted 100-fold and 15-fold, after which the photometer was adjusted to the Ca, $\mathrm{Mg}$ position and each tube was passed through the apparatus.

Potassium is widely distributed in the environment and included in natural waters. However, during water treatment, potassium permanganate is sometimes used at the same time that the oxidant is released into the drinking water. The concentrations of the potassium sites did not exceed the limit acceptable by WHO $(12 \mathrm{mg} / \mathrm{L})$.

Sodium is highly soluble and is often found in groundwater in its natural state. Sodium is also present in many rocks and soils, as well as in many foods. Sodium concentrations in the sites did not surpass the allowable WHO limit of $150 \mathrm{mg} / \mathrm{L}$ [9].

Ammonium in water usually reflects a process of incomplete degradation of organic matter. It comes from the reaction of minerals containing iron with nitrates. It is therefore an excellent indicator of water pollution by organic discharges of agricultural, domestic and/or industrial origin. It was noticed that all the ammonium concentrations in the various sites were between 0 and $0.150 \mathrm{mg} / \mathrm{L}$ [10]. It is worth note mentioning that all results were acceptable and did not exceed the limit determined by the WHO (which is equal to $0.2 \mathrm{mg} / \mathrm{L}$ ) except for Borj Rahal and Ain Abou Abdallah sites (2).

Calcium is very abundant naturally. Its most common sources in the waters are rocks and minerals as calcite. High concentrations of calcium can cause intestinal diseases and kidney stones [10]. Concentrations of Calcium in Borj Rahal, Qasmieh, Zrarieh (2), Chhour (3) and Arzoun sites vary between 125 and 240 $\mathrm{mg} / \mathrm{L}$, not exceeding the allowable WHO limit of $250 \mathrm{mg} / \mathrm{l}$ [9]. Thus, no contamination from this parameter in case for these sites, unlike other ones that have high levels.

The most common source of magnesium is erosion of rocks and minerals such as magnetite. High levels of magnesium can cause cardiovascular diseases and elevated rate of water hardness [11]. Magnesium levels in the sites did not exceed the permissible WHO limit of $50 \mathrm{mg} / \mathrm{L}$.

\subsubsection{Heavy metals}

Lead comes from an ore of galena which can be used directly in metallurgy, particularly under the Roman Empire through used coins, pipes, household utensils and also during the industrial revolution. Lead in all sites exceeded the WHO acceptable limit $(0.01 \mathrm{mg} / \mathrm{L})$. The highest values are $(0.0809 \mathrm{mg} / \mathrm{L})$ and $(0.0642 \mathrm{mg} / \mathrm{L})$ for Zrarieh (1) and Chhour (2) sites respectively. Tar Felsai, Chhour (3), Arzoun, $(1,2)$ and Kaakeih el Jeser did not exceed the limit $(0 \mathrm{mg} / \mathrm{L})$.

Iron is an indispensable metal for the survival of living beings. Indeed, the iron gives its red color to the blood. It is used to make red blood cell sand to produce hemoglobin. The latter transports oxygen to the cells. In addition, iron present in sediments creates a favorable environment for certain types of bacteria. Thus, it might be directly correlated with excessive bacterial activity. Iron levels in all selected points were in conformity with WHO allowable limit of $0.3 \mathrm{mg} / \mathrm{L}$.

Cadmium is a minor constituent of various metal ores. Its physicochemical properties pinpoint to the fact that it can have multiusage functions in, batteries, anti-corrosion protection and as a stabilizer in plastics and pigments. A concentration of this element in all sites was $0 \mathrm{mg} / \mathrm{L}$ not exceeding the WHO acceptable limits for cadmium $(5 \mathrm{mg} / \mathrm{L})$.

Chrome is present in small amounts in its natural state in all types of rocks and soils. The main anthropogenic contributions of chromium and its compounds are atmospheric deposition and the spreading of sewage sludge [12]. The concentrations of these elements in all sites did not exceed the WHO acceptable limits for chrome $(0.05 \mathrm{mg} / \mathrm{L})$.

Copper is a reddish metal with a high thermal and electrical conductivity at room temperature. It can be retained by sediments and is often associated with clay minerals due to the formation of highly stable copper organic compounds. Copper is known for its complication by natural organic matter. The major sources of $\mathrm{Cu}$ are related to agrochemical compounds (especially phosphate fertilizers) and residential waste. Copper at high concentrations can cause neurodegenerative diseases [13]. The examined sites did not exceed the acceptable limit set by WHO $(1 \mathrm{mg} / \mathrm{L})$.

Zinc is an essential metal for the life of a large number of organisms and necessary for certain physiological processes. However, at high concentrations, it becomes toxic to living organisms. It has the ability to associate preferentially with fine particles or to adsorb to clay minerals. It comes mainly from industries and the use of manures [14]. The concentrations of these elements in the sites did not exceed the permissible WHO limit OF $(5 \mathrm{mg} / \mathrm{L})$. 


\section{$5 \quad$ Statistical Analysis}

Data diagnosing by Principal Component Analysis (PCA) was performed by Spadv55 software. There are several statistical methods that can summarized the information contained in a data matrix. Among these, Principal Component Analysis (PCA) that allows to reduce the number of variables and to detect a structure in the relations between variables.

\subsection{Principal Component Analysis (PCA)}

The reduction of the data using a factor analysis is based on the rotation logic of the axes. In a twodimensional space when two variables $\mathrm{X}$ and Yare correlated, they define a cloud of points having a particular shape and structure. To study the structure of this cloud, it is reduced from several points of view. For example, we search for the central tendency, taking the average of all the variables $\mathrm{X}$ and the average of all the variables Y. The use of Principal Component Analysis involves a definite data analysis strategy.

\subsection{Correlation of Physical and Chemical Parameters}

Parameter variations were evaluated using the correlation matrix using the correlation coefficient (Table 4). The correlation matrix determines the variance of each constituent.

Table 4. The correlation matrix of physical and chemical parameters.

\begin{tabular}{|c|c|c|c|c|c|c|c|c|c|c|c|c|c|c|c|}
\hline & EC & TDS & $\mathrm{PH}$ & $\mathrm{SO}_{4}{ }^{2-}$ & $\mathrm{NH}_{4}{ }^{+}$ & $\mathrm{PO}_{4}{ }^{3-}$ & $\mathrm{NO}_{3}^{-}$ & $\mathrm{Pb}$ & $\mathrm{Cu}$ & $\mathrm{Zn}$ & $\mathrm{Cr}$ & $\mathrm{Ca}^{2+}$ & $\mathrm{Mg}^{2+}$ & $\mathbf{K}^{+}$ & $\mathrm{Na}^{+}$ \\
\hline EC & 1.00 & & & & & & & & & & & & & & \\
\hline TDS & 1.00 & 1.00 & & & & & & & & & & & & & \\
\hline $\mathrm{PH}$ & -0.03 & -0.03 & 1.00 & & & & & & & & & & & & \\
\hline $\mathrm{SO}_{4}{ }^{2-}$ & 0.29 & 0.28 & 0.21 & 1.00 & & & & & & & & & & & \\
\hline $\mathrm{NH}_{4}{ }^{+}$ & 0.10 & 0.10 & 0.04 & -0.08 & 1.00 & & & & & & & & & & \\
\hline $\mathrm{PO}_{4}{ }^{3}$ & 0.56 & 0.58 & 0.52 & -0.15 & 0.11 & 1.00 & & & & & & & & & \\
\hline $\mathrm{NO}_{3}{ }^{-}$ & 0.43 & 0.45 & 0.30 & -0.18 & 0.38 & 0.72 & 1.00 & & & & & & & & \\
\hline $\mathrm{Pb}$ & 0.21 & 0.24 & 0.07 & -0.22 & 0.18 & 0.39 & 0.30 & 1.00 & & & & & & & \\
\hline $\mathrm{Cu}$ & -0.12 & -0.15 & -0.41 & -0.11 & -0.11 & -0.43 & -0.43 & -0.39 & 1.00 & & & & & & \\
\hline Zn & -0.11 & -0.13 & -0.41 & -0.15 & -0.21 & -0.25 & -0.25 & -0.41 & 0.49 & 1.00 & & & & & \\
\hline $\mathrm{Cr}$ & 0.27 & 0.27 & 0.10 & -0.11 & 0.74 & 0.40 & 0.44 & 0.12 & -0.17 & -0.21 & 1.00 & & & & \\
\hline $\mathrm{Ca}^{2+}$ & 0.43 & 0.40 & -0.29 & 0.51 & -0.09 & -0.24 & -0.07 & -0.20 & 0.39 & 0.39 & -0.20 & 1.00 & & & \\
\hline $\mathrm{Mg}^{2+}$ & 0.62 & 0.64 & -0.26 & -0.41 & 0.12 & 0.59 & 0.44 & 0.30 & -0.05 & -0.01 & 0.44 & -0.12 & 1.00 & & \\
\hline $\mathbf{K}^{+}$ & 0.54 & 0.52 & 0.11 & 0.79 & -0.22 & 0.09 & -0.01 & -0.17 & -0.08 & -0.03 & -0.17 & 0.49 & -0.11 & 1.00 & \\
\hline $\mathrm{Na}^{+}$ & 0.68 & 0.68 & -0.09 & 0.69 & 0.07 & 0.19 & 0.14 & -0.11 & -0.18 & -0.14 & 0.23 & 0.33 & 0.25 & 0.80 & 1.00 \\
\hline
\end{tabular}

\subsection{Principal Component Analysis (PCA) of Physical and Chemical Parameters}

Since the variables $\mathrm{x}$ have significantly different variances (different scales of the values), the PCA decomposition is applied to the correlation matrix that is to say on the $\mathrm{X}$ " $\mathrm{X}$ matrix of the centered and reduced (standardized) X data. The table of eigenvalues (Table 5) shows that the first three principal components (PC1, PC2 and PC3), which explain approximately $68.16 \%$ of the variability or correlations of the initial data $(\mathrm{x})$ are significant with eigenvalues $\lambda>1$. 
Table 5. Eigenvalues.

\begin{tabular}{cccc}
\hline Number & Own value & Percentage & Cumulative percentage \\
\hline $\mathbf{1}$ & 4.5712 & 30.47 & 30.47 \\
$\mathbf{2}$ & 3.4894 & 23.26 & 53.74 \\
$\mathbf{3}$ & 2.1642 & 14.43 & 68.16 \\
\hline
\end{tabular}

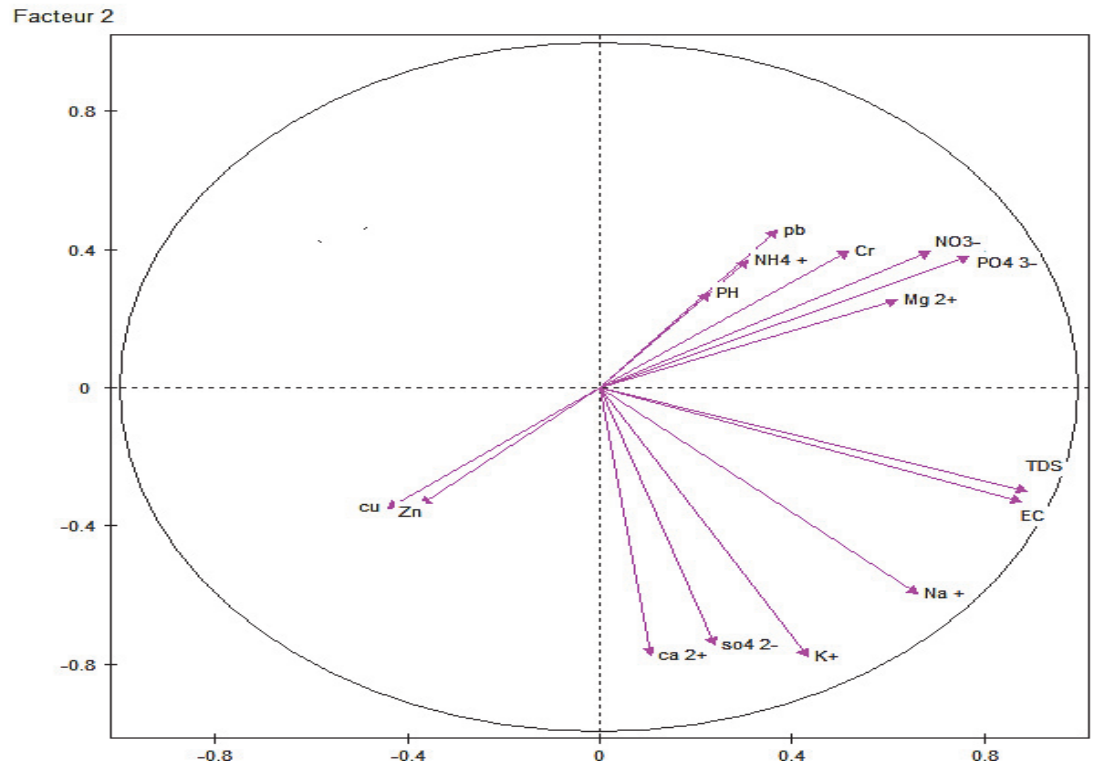

Figure 3. The circle of correlation of different variables in $\mathrm{C} 1$ and $\mathrm{C} 2$

The extraction of the factorial axes (still called principal components or more simply factors) makes it possible to obtain a better representation of the distances between the variables on the one hand and the samples on the other hand.

Factor 1 (PC1) (Figure 3) showed linearly separates the variables: phosphate, nitrate, magnesium, sodium, TDS, and EC, that are assigned to positive values, and also separates Zinc, and assigned copper to negative values, so the phosphate is positively correlated with magnesium, nitrate, sodium, TDS, and EC. These values are negatively correlated with zinc, copper. PC1 separates sites with relatively high phosphate, nitrate, magnesium, sodium, TDS, and EC values, and relatively low zinc, copper values, also sites with phosphate, nitrate, magnesium, sodium, TDS, EC, relatively low and zinc values, and relatively high Copper.

The factor 2 (PC2) linearly separates the variables as ammonium, chromium, and lead that were associated with positive values, whereas calcium, sulfate, potassium associated with negative values, so PC2 separates the sites having the values of the variables ammonium, chromium, and lead relatively with high values and relatively with low calcium, sulfate, potassium values. It can be noticed also sites with relatively low ammonium, chromium, and Lead values, and relatively high calcium, sulfate and potassium values.

\subsection{Relation between Sites and Sources of Pollution}

$\mathrm{C} 1 \times \mathrm{C} 2$ factor map analysis (Figure 4$)$ identified three classes of samples. The class $(1 / 3)$ is on the positive side of the $\mathrm{C} 1$ and $\mathrm{C} 2$ axis, and the class $(2 / 3)$ is on the positive side of the $\mathrm{C} 1$ axis and the negative side of the $\mathrm{C} 2$ axis, while the axis $(3 / 3)$ is on the negative side of the $\mathrm{C} 1$ axis and the positive side of the $\mathrm{C} 2$ axis. 


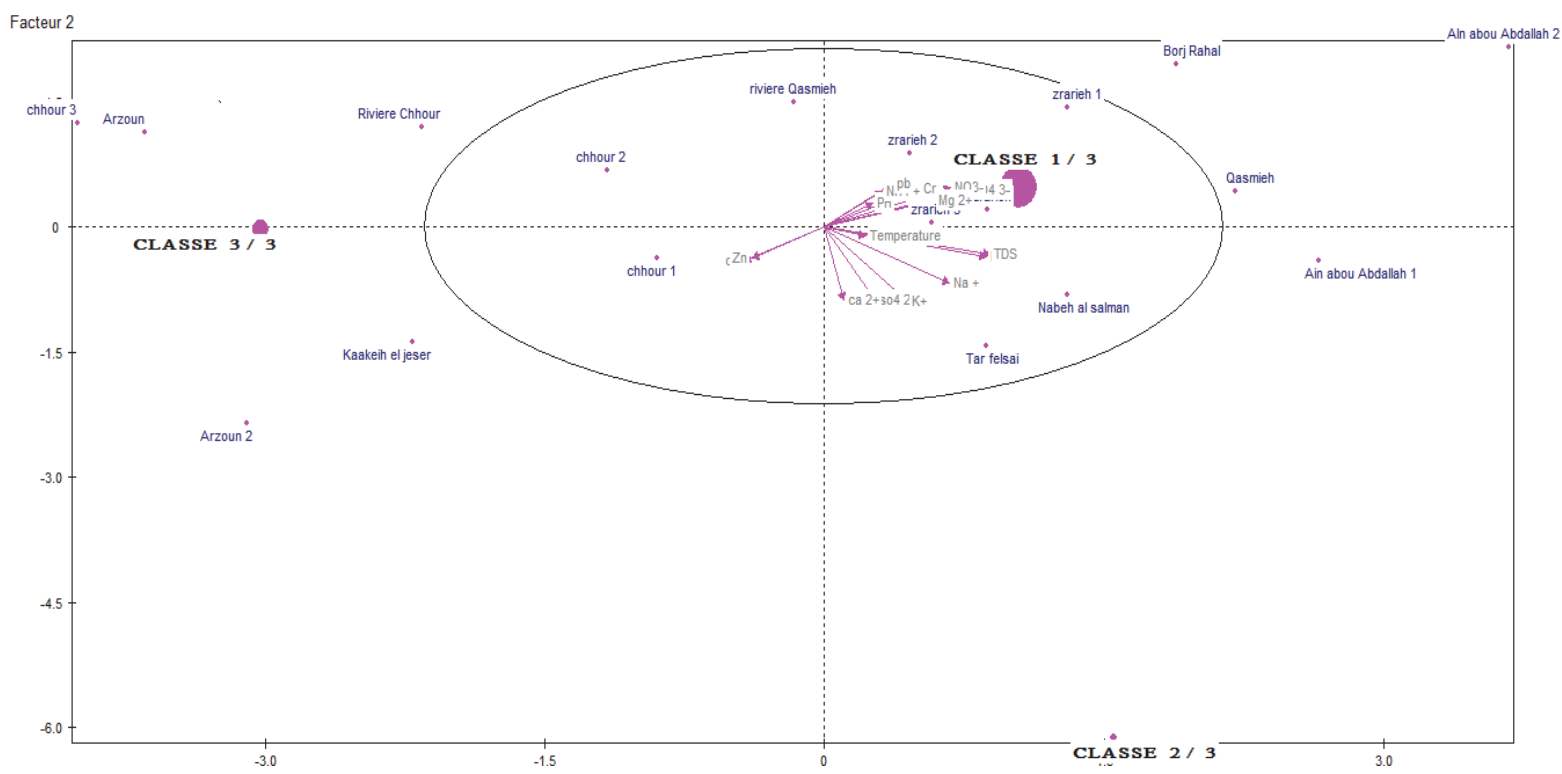

Figure 4. The $\mathrm{C} 1 \times \mathrm{C} 2$ factor map.

Classes (2/3) and (3/3) are opposite to C1 and C 2, classes (1/3) and (2/3) are opposite to C2, and classes $(1 / 3)$ and $(3 / 3)$ are opposed to $\mathrm{C} 1$.

Sites of first class (1/3): Borj Rahal, Ain Abou Abdallah (1), Qasmieh, Zrarieh, Zrarieh $(1,2,3)$, Nabeh al Salman, Tar Felsai, and Chhour (1) show a concentration with high nitrate, lead, calcium and sulfate. This PCA shows that these sites are contaminated due to the agricultural activities, discharge of wastewater or industrial wastes.

Site of second class (2/3): Ain Abou Abdallah (2), Qasmieh River, Chhour (2), Arzoun (1) show a high concentration of calcium, nitrate and sulfate. This PCA shows that the sites are contaminated due to erosion of rocks, and the presence of industrial wastes.

Site of third class (3/3): Chhour River, Chhour (3), Arzoun, Arzoun (2), and Kaakeih el Jeser show a high concentration of sulfate, calcium and the total absence of phosphate. This PCA shows that these sites are contaminated due to the presence of sediments that are associated with clay minerals, and the presence of industrial spoils.

\subsection{Principal Component Analysis (PCA) of Microbiological Analysis}

Table 6. The correlation matrix of the microbiological analysis

\begin{tabular}{ccccc}
\hline Correlation matrix & Total Coliformes & Eishershia coli - EC & Salmonella & Staphylococcus Aureus \\
\hline Total coliformes & 1.00 & & & \\
Eishershia coli - EC & 0.29 & 1.00 & 1.00 & \\
SS & 0.05 & -0.26 & 0.04 & \\
Staphylococcus Aureus & -0.36 & -0.31 & & \\
\hline - & Strong correlation $(0.5<\mathrm{r}<0.8)$ & & \\
- $\quad$ Mean correlation $(0.2<\mathrm{r}<0.5)$ & & \\
- Weak correlation $(\mathrm{r}<0.2)$ &
\end{tabular}

Parameter variations were evaluated using the correlation matrix using the correlation coefficient (Table 6). The correlation matrix determined the variance of each constituent. Since the variables $\mathrm{X}$ have significantly different variances or different scales of the values, the PCA decomposition is applied to the correlation matrix that is clear on the X "X matrix of the centered and reduced standardized X data. The table of eigenvalues (Table 7) shows that the first three principal components (PC1, $\mathrm{PC} 2$ ) which explain 
approximately $69.35 \%$ of the variability or correlations of the initial data $(\mathrm{x})$ are significant with eigenvalues $\lambda>1$.

Table 7. The eigenvalues.

\begin{tabular}{cccc}
\hline Number & Own value & Percentage & Cumulative percentage \\
\hline 1 & 1.5251 & 41.73 & 41.73 \\
2 & 1.1608 & 27.62 & 69.35 \\
\hline
\end{tabular}

\subsection{Interpretation of PCA}

The factor 1 (PC1) (Figure 5) linearly separates the variables of Staphylococcus Aureus that assigned to a positive value, and also separates total coliform assigned to a negative value. Thus, Staphylococcus Aureus is positively correlated with salmonella and negatively correlated with Eishershia coli, and total coliform. PC1 separates sites with relatively high Staphylococcus Aureus variable.

The factor 2 (PC2) linearly separates the salmonella variable associated with a positive value and Eishershia - coli associated with a negative value, so salmonella is positively correlated with Staphylococcus Aureus, total coliform, and negatively correlated with Eishershia - coli. PC2 separates sites with relatively high Eishershia-coli values and relatively low Salmonella values from sites with relatively low Eishershiacoli values and relatively high Salmonella values.

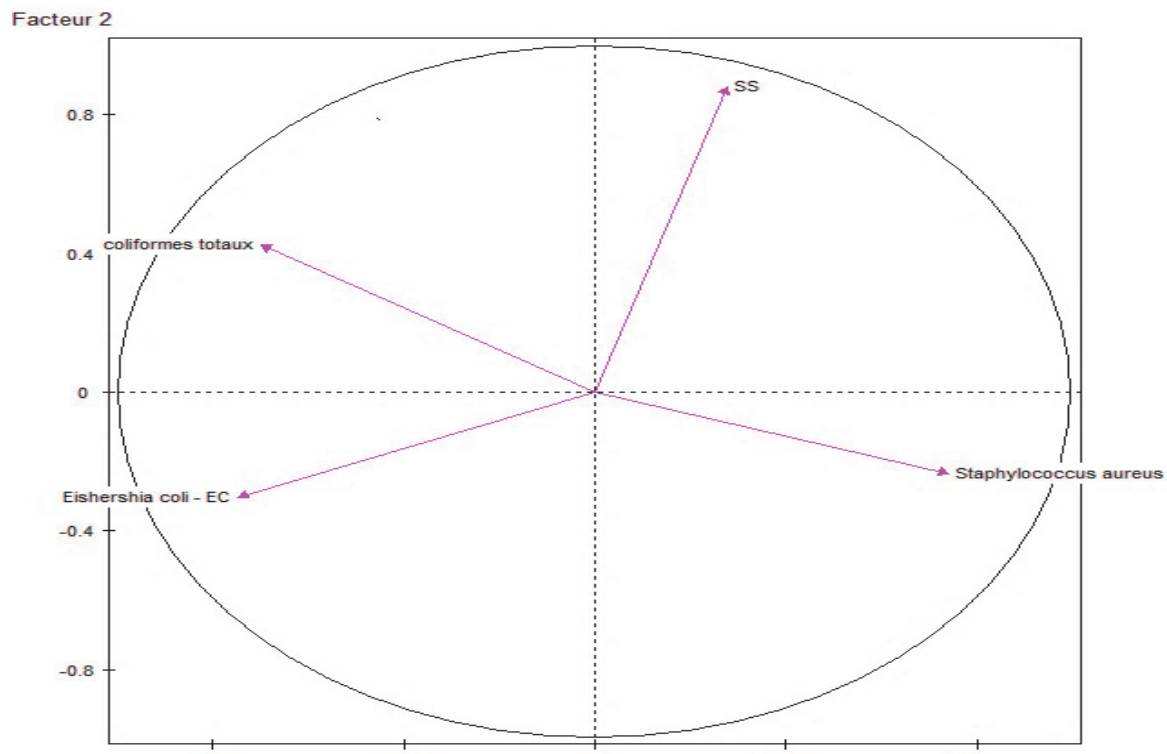

Figure 5. The circle of correlation of different variables in $\mathrm{C} 1$ and $\mathrm{C} 2$.

\subsection{Relationship between Sites and Sources of Pollution}

$\mathrm{C} 1 \times \mathrm{C} 2$ factor map analysis (Figure 6) identified three classes of samples. The class $(1 / 3)$ is on the positive side of the $\mathrm{C} 1$ axis and the negative side of the $\mathrm{C} 2$ axis, and the class $(2 / 3)$ is on the positive side of the $\mathrm{C} 1, \mathrm{C} 2$ axis, while the axis $(3 / 3)$ is on the negative side of the $\mathrm{C} 1$ axis and the positive side of the $\mathrm{C} 2$ axis. The classes $(1 / 3)$ and $(2 / 3)$ are opposed to the class $(3 / 3)$ to $\mathrm{C} 1$ and $\mathrm{C} 2$, the classes $(2 / 3)$ and $(3 / 3)$ are opposed to the class $(1 / 3)$ to C2. The sites of the first class (1/3): Borj Rahal, Ain Abou Abdallah (1), Zrarieh, Zrarieh (1,2,3) Nabeh al Salman, Tar Felsai, Chhour (3), and Arzoun (2) show a low concentration of Staphylococcus Aureus and Eishershia -coli. The sites of the second class (2/3): Ain Abou Abdallah (2), Qasmieh River, Chhour River, Chhour (1), and Arzoun (1) show a high concentration 
of salmonella, and Staphylococcus Aureus. The site of the third class (3/3): Qasmieh, Chhour (2), Arzoun, and Kaakeih El Jeser show a high concentration of total coliform.

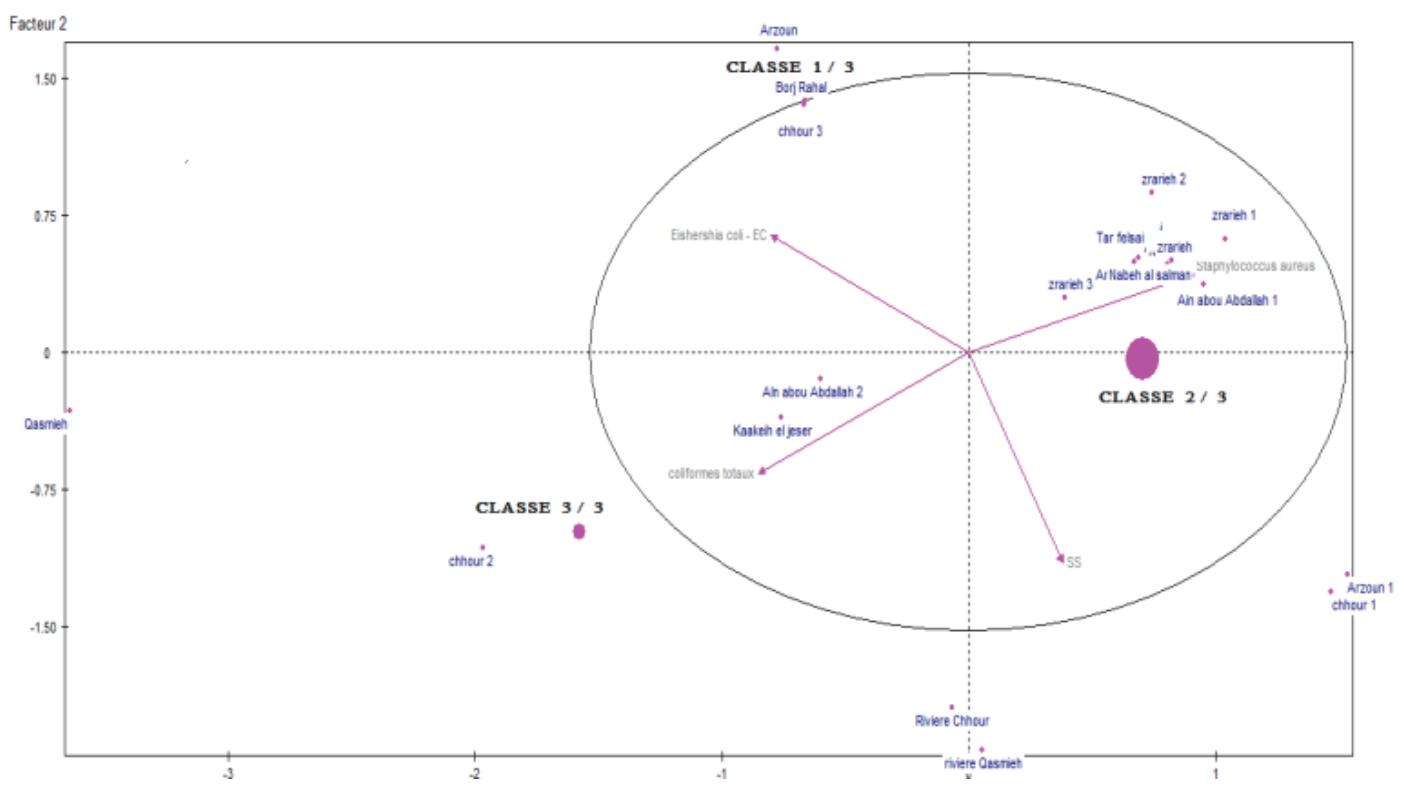

Figure 6. The circle of correlation of different variables in $\mathrm{C} 1$ and $\mathrm{C} 2$.

\section{Conclusion}

This study focused on a distinctive insight on the vulnerability of groundwater quality in the LLRB caused by the influence of karstic geological formations and anthropogenic activities. Unsustainable agricultural practices majorly impact groundwater quality. However, the risk of wastewater and SW from urbanized agglomerations and industrial enterprises is rapidly becoming highly alarming given the sudden increase in population due to the Syrian conflict and inflow of refugees into the country.

Groundwater seems to be a crucial factor with varied beneficial effects on different sectors of the life of the inhabitants mainly in terms of domestic and agricultural uses. For this reason, the study of groundwater in sites of the lower Litani were selected for undergoing physicochemical analysis of water parameters as $\mathrm{T}, \mathrm{PH}, \mathrm{EC}$ and $\mathrm{TDS}$, anion content $\left(\mathrm{NO}^{3-}, \mathrm{SO}_{4}{ }^{2-}, \mathrm{C}^{-}\right.$and $\left.\mathrm{PO}_{4}{ }^{3-}\right)$, cation content $\left(\mathrm{Na}^{+}, \mathrm{K}^{+}\right.$, $\mathrm{Ca}^{2+}, \mathrm{NH}_{4}{ }^{+}$and $\mathrm{Mg}^{2+}$ ), and the metal content of $\mathrm{Cd}, \mathrm{Cr}, \mathrm{Fe}, \mathrm{Pb}, \mathrm{Cu}$ and $\mathrm{Zn}$. The observed microbiological parameters were: Salmonella, Escherichia coli, Total coliforms, Clostridium perfringens and Staphylococcus Aureus.

The study indicated that the sites were not contaminated with magnesium, ammonium, sodium, potassium, chloride and phosphate since their concentrations were generally below the standards set for the WHO. However, contamination by other elements was the case in some sites which showed concentrations higher than the acceptable limits. This pollution was revealed by nitrate, sulfate, calcium and bacteria. It can be explained by the usage of fertilizers in agriculture on one hand, and on other hand a mixture with sewage. So the quality of water is attenuated in these sites. Most of them were contaminated with lead. However, the values of heavy metals in water as $\mathrm{Cd}, \mathrm{Cr}, \mathrm{Fe}, \mathrm{Cu}$ and $\mathrm{Zn}$ were null.

Microbial pollution was clearly visible in all investigated sites. This can be attributed to several factors as domestic wastes, wastewater, tourist activities and rejections of the agricultural waste. Based on the mentioned above conclusions it can be drawn as follows:

- It could be argued that all sites were contaminated with total coliform except Ain Abou Abdallah (1). There are sites that have a very high contamination rate and that exceed the acceptable limit.

- All sites were contaminated by Escherichia - Coli except Ain Abou Abdallah (1, 2). There are sites that have a very high contamination rate and that exceed the acceptable limit. 
- All sites were contaminated with Salmonella except Qasmieh, Zrarieh, Zrarieh (2), Arzoun (2) and Kaakeih el Jeser.

- All sites were contaminated with Staphylococcus Aureus. There are sites that have high contamination levels and that exceed the limit. No contamination by Clostridium perfringens was detected.

Regarding the physicochemical parameters analysis, it was found out that the values of T, TDS, EC and $\mathrm{PH}$ were acceptable. The ACP of statistical analysis has shown that the site of Ain Abou Abdallah (2) is the most polluted site.

In view of the above mentioned results, some actions are recommended and could be taken into consideration from governmental institution and private sector with aim to mitigate or to avoid the risks of pollution. Establishment of wastewater-treatment systems along the Litani River, notably where levels of pollution are high is very important to protect the river. Secondly, oblige existing factories must installed treatment system based on their particular type of industrial waste and solid waste to avoid water and air pollution. Very important for launch campaigns that recommended the use of fertilizers and pesticides in rational amounts.

The sources of pollution are well defined in each region. Elimination of those sources required serious implementations which are lacking from different parties in the country as:

1. Absence of the required implementations (e.g., infrastructures, landfills, treatments plants, channels, etc.) to mitigate or decrease pollution.

2. Absence of transparency leading to corruption and exhaustion of the financial resources.

3. Lack of coordination and cooperation between the concerned sectors on water resources, agriculture, and environment.

4. Weakness in the application of legislations for water consumption from the Litani River and Qaraaoun Reservoir.

5. Lack of consolidated environmental policies and legislations. The existing environmental laws are almost generic and not well applied.

6. Lack of awareness coupled with the poor ethical conduct of polluters at times.

By interpretation of the results, the main pressures affecting groundwater in the lower Litani basin and their impacts are:

1. Water quality deterioration is mainly due to untreated water discharges into shallow and underground streams.

2. The discharge of industrial effluents untreated into superficial streams.

3. Irrigation of the river bed in summer with sewage that contaminates soil and groundwater by infiltration.

4. The use of an exaggerated amount of fertilizers and pesticides in agriculture with their related negative impacts on groundwater.

Acknowledgment. The authors extend their gratitude to Prof. Amin Shaban for his support of this study, and thanks to Dr Ihab Jomaa, Head of Department of Irrigation and Agro meteorology for his help for preparation of GIS maps. Thanks also are due to the anonymous reviewers for reviewing of this paper and for their important comments.

Conflict of Interest. The authors declare no conflicts of interest regarding the publication of this paper.

\section{References}

1. Shaban A, Hamze M., 2017. Shared water resources of Lebanon, Nova, and NY. P.150.

2. Shaban, A., 2003. Etude de l'hydroélogie au Liban Occidental: Utilisation de la télédétection. Ph.D. dissertation. Bordeaux 1 Université. 202pp.

3. Comair F., 2010. Water Resources in Lebanon, Documentation provided by Dr Comair, DGof Water and Electrical Resources, MOEW to ECODIT, November,2010.

4. USAID., 2005. Lebanon's Basin Management Advisory Services: Technical Survey Report. Summer Conditions.

5. Jaber B., 2002. Water problems of Lebanon. National Congress on Water Strategic Studies Center. Beirut (in Arabic). P.67 
6. Faour G., 2015. Evaluating urban expansion using remotely-sensed data in Lebanon. Lebanese Science Journal.2, $50-62$.

7. Haddad N, 2001.Surveillance de la qualité de l'eau de la rivière Litani lebanese Science Journal. 81-87.

8. Hajjar Z., 1997. L'eau du Liban et la paix au Moyen-Orient, Beyrouth, Dar-ilm-lilmalayin.P.397.

9. Nehme, N., 2014. Evaluation de la qualité de l'eau du bassin inférieur de la rivière du Litani, Liban: Approche environnementale. France: Université de Lorraine. PhD Thesis.

10. Subin, H., 2013. An Assessment on the Impact of Waste Discharge on Water Quality of Priyar River Lets in Certain Selected Sites in the Northern Part of Ernakulum District in Kerala, India. International Research Journal of Environment Sciences, 2,8.

11. Radoux D, Heincn E, Kinct-Denoēl C, Tihange E, Simar L. J., 1984. -Precise localization of antigens on follicular dendritic cells. $\|$ Cell Tiss. Res. 235: 267-274.

12. Postel G, Ehrlich. P., 1996. Human Appropriation of Renewable Fresh Water. American Association for the Advancement of Science, 5: 271.

13. Gannam G, Ayoub G, Acra A., 1998. A profile of the submarine springs in Lebanon as a potential water resource. Water international, 23:278-286.

14. Nada N, Chaden H, Walaa D, Tarawneh K, Frédéric V., 2019. Assessment of Heavy Metal Pollution in the Sediments of the Lower Litani River Basin, Lebanon. Jordan Journal of Earth and Environmental Sciences, 10 (2): 104-112. 